\title{
DIETARY VALUES OF WILD AND SEMI-WILD \\ EDIBLE PLANTS IN SOUTHERN ETHIOPIA
}

Getachew Addis $\mathrm{G}^{1 *}$, Asfaw $\mathrm{Z}^{2}$, Singh $\mathrm{V}^{3}$, Woldu $\mathrm{Z}^{2}$, Baidu-Forson $\mathrm{JJ}^{4}$ and $S$ Bhattacharya ${ }^{3}$

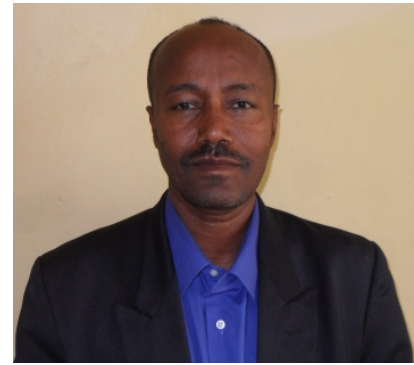

Getachew Addis

*Corresponding address email: get_ast@yahoo.com

${ }^{1}$ Ethiopian Health and Nutrition Research Institute, P.O. Box 1242, Addis Ababa, Ethiopia

${ }^{2}$ Department of Biology, Addis Ababa University, P O Box 3434, Addis Ababa, Ethiopia

${ }^{3}$ Department of Grain Science and Technology, Central Food Technological Research Institute, Mysore-570 020, India

${ }^{4}$ Bioversity International, P.O. Box 30677, Nairobi 00100, Kenya 


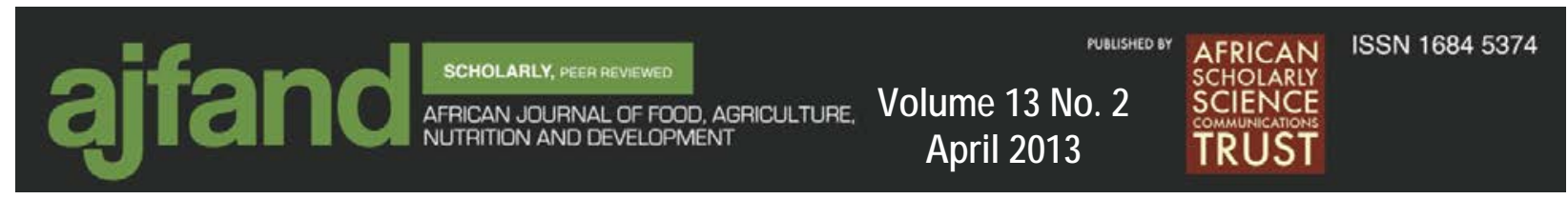

\begin{abstract}
Ethnobotanical studies have shown that many wild plant species are sporadically consumed alongside regular food sources in developing countries. Many plants of wild and semi-wild origin are consumed in the remote parts of southern Ethiopia. Dietetic values of Ethiopia's non-crop food plants, though important in prevention of malnutrition and contribution to food security, remains shrouded for lack of chemical information. The chemical composition of popularly used wild edibles in Hamar and Konso (Xonso) of southern Ethiopia was examined. The most preferred 15 semi-wild and wild edible plants were selected using a mix of standard ethnobotanical field methods. Edible parts of target plants were collected with local participants, lyophilized and analyzed for proximate composition, amino acids, minerals and antinutritional factors. The wild edibles constituted good amounts of nutrients essential in human diet. Green leafy vegetables (GLVs) gave 1.5-5.8\% ether extractives and total mineral composition of 12.5\%-25.6\%; Ca being highest (1100 - $3419 \mathrm{mg} \%$ ) and exceptionally high for Justicia ladanoides (6177 mg \%). Fe, Mg, Mn and Zn ranged from 11.7-23.14, 175-2049, 3.4-9.9 and 1.2-3.3 mg \%, respectively. All GLVs contained $\geq 20 \%$ protein, highest in Coccinia grandis (36.3\%). The latter species and Trigonella foenum-graecum yielded high lysine level. Anti-nutrients of concern include phenolics (158-1564 mg \%) and tannins (448-2254 mg \%) in GLVs and phenolics (1997mg \%) and tannins (6314 mg \%) in Ximenia caffra fruits. Total oxalates in mg \% were high in Amaranthus graecizans (14067), Celosia argentea (12706) and Portulaca quadrifida (10162). Bulk consumption of monotype edible plant part in one meal may lead to nutritional and health impairment. However, traditional processing methods lower most of the anti-nutritionals and their respective risks. New food composition tables that integrate indigenous knowledge and nutritional content of the semi-wild and wild edibles are recommended. Wild edibles can be considered to improve livelihood security and reduce malnutrition in tune with the Millennium Development Goals aimed at reducing poverty and hunger.
\end{abstract}

Key words: GLVs, Hamar, Konso, nutrients, anti-nutrients 


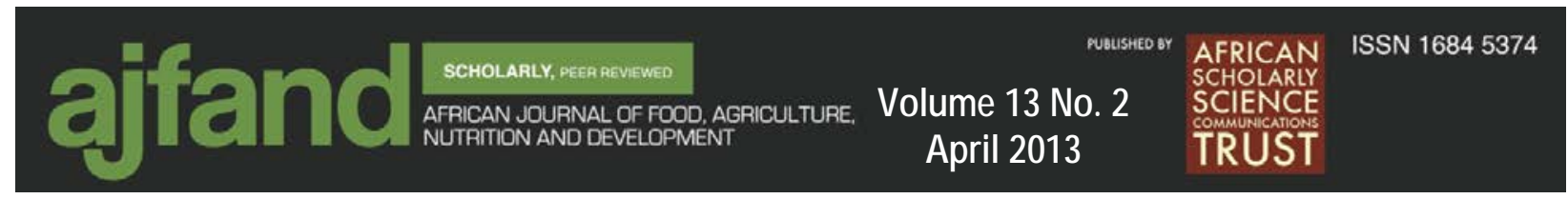

\section{INTRODUCTION}

A serious challenge to human survival, particularly in the developing world, is the ever growing gap between human population and food supply. Research and development focused on the lesser known edible plants could assist in narrowing the gap between population growth and food deficiency currently escalating in developing countries. Ethiopia has been affected by recurrent drought and famine; but the coping mechanisms were largely sourced from foreign aid rather than being inward looking and development-oriented. Growing and using wild vegetables is an opportunity that has never been adequately prospected to alleviate malnutrition and ameliorate food insecurity.

On the other hand, hundreds of edibles including many vegetables of wild/semi-wild origin are known to be sporadically consumed by rural communities in Ethiopia. A recent book [1] included 378 wild plant species known to be consumed in parts of Ethiopia with descriptions of many. Earlier sources, though scattered, presented about the same number of species. The actual number of wild edible plants in Ethiopia is expected to be more than the presently cited number given a large flora of more than 6000 species, many cultures and localities that as yet remain ethnobotanically unexplored. The proportion of wild vegetables is known to be high and the degree of consumption varies from one socio-cultural setting to the other [2]. Except in few cases of south Ethiopian communities and some others, consumption of underutilized edible plants, vegetables in particular, has often been looked upon as a sign of poverty; largely a reflection of lack of knowledge on their nutritional benefits. Fast regeneration of most vegetables under limited soil moisture and availability of the perennial species all year round makes them capable of bridging the gap during food shortages and famine situations experienced by rural communities [3-8].

Domesticated and non-domesticated green leafy vegetables (GLVs) have numerous dietary and health benefits. They are inexpensive, easy to cook, and are rich sources of macro- and micronutrients [9-12]. Regular consumption of vegetables is also recommended for better health and management of chronic diseases such as cardiovascular complications, diabetes and cancer [13]. Research has shown that indigenous communities in East Africa have dietary additives of wild plant material that contain antioxidants to degrade cholesterol from their traditional foods of meat, milk and blood [14]. There are also concerns that higher intake of GLVs may increase ingestion of anti-nutrients that impair bioavailability of nutrients such as tannins, phytates and oxalates or directly cause illnesses or fatality such as haemolysis and even death due to excessive ingestion of lectins [13]. Despite the actual and potential benefits, research into the GLVs has to a large extent not been a priority concern in Ethiopia; GLVs are yet to emerge as an area of focus in the development sector.

The ever widening gap between population growth and production of conventional crops, recurrent food deficits, and higher prevalence of macro- and micronutrient malnutrition with increasing cases of chronic diseases make diversification of food sources a worthwhile endeavour wherein wild edibles claim their share. Aspirations 


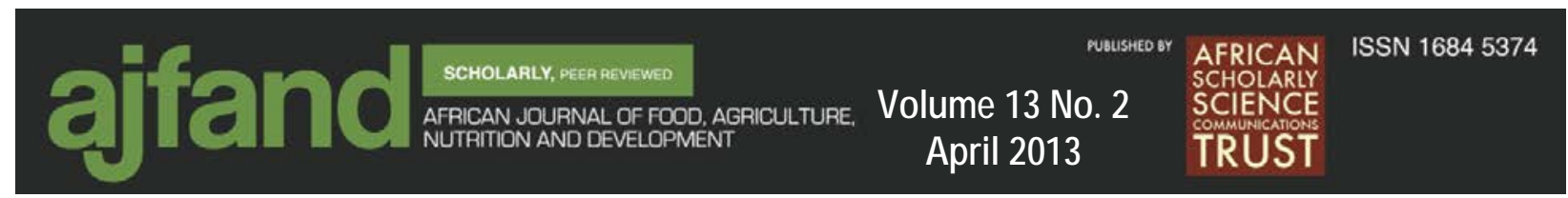

of developing countries like Ethiopia to create healthy, productive and food and nutrition secure communities could come true through effective application of indigenous knowledge [15]. The objective of this study was to investigate nutritional quality and anti-nutritional composition of the edible parts of most preferred underutilized edible plants collected from Hamar and Konso of southern Ethiopia and shed light on the correspondence relationship between ethnobotanical knowledge and chemical information.

\section{MATERIALS AND METHODS}

\section{The study area}

This study was conducted in Hamar District $\left(4^{0} 45^{\prime}\right.$ to $5^{0} 18^{\prime} \mathrm{N}$, and $36^{0} 14^{\prime}$ to $36^{\circ} 41^{\prime} \mathrm{E}$ ) about $900 \mathrm{~km}$ and Konso Special District ( $5^{0} 15^{\prime}$ to $5^{0} 30^{\prime} \mathrm{N}$, and $37^{0} 15^{\prime}$ to $37^{0} 30^{\prime} \mathrm{E}$ ) about $600 \mathrm{~km}$ south of Addis Ababa in the southern region of Ethiopia. Both study areas are located in the dryland part of the southern Ethiopian Rift Valley system and the adjoining areas.

\section{Selection of edibles and voucher specimen collection}

Through an initial ethnobotanical survey of wild/semi-wild edible plants of Hamar and Konso districts (2006-2009), detailed ethnobotanical knowledge was recorded while collecting voucher specimens. Vouchers of wild edible plant species were collected with knowledgeable local participants and the botanical determination was made by the principal investigator using the various volumes of the modern Flora of Ethiopia, and checking against identified specimens found in the National Herbarium of Addis Ababa University (Ethiopia).

Preliminary selection of edible plant parts from five kebeles (lowest administrative structure in Ethiopia) in each district was undertaken using focus group discussion (FGD) where participants were requested to list down ten most preferred and most consumed species of wild and semi-wild origin used by the community as GLVs, three used as fruits and three used as other. The target species for chemical analysis were selected after obtaining detailed information through ranking and comparison exercises and their edible parts collected. The overall community acceptance as food of the plant part, preference and consumption by household members irrespective of age, gender, and economic background were used as criteria for picking the target edibles. For selection of edible plant parts, unlike the preference ranking technique suggested by Martin [16], and used by many other researchers to rank using individual participants, FGD technique was preferred and motivated to list the GLV from the most liked to the least liked. The sum of the preference scores for each edible part in each kebele was taken as overall rank in the respective study district. Accordingly, among 240 edible plant parts mentioned in reference to the 206 edible wild/semi-wild plant species determined earlier [2], 15 species consisting of edible parts were finally selected based on combination of different criteria. The criteria included 1) higher preference value of the edible parts in each district, 2) edibility of the plant part for extended period of the year, 3) better harvesting value and ease of collection, 4) wider distribution across different agroecological zones, 5) use during 


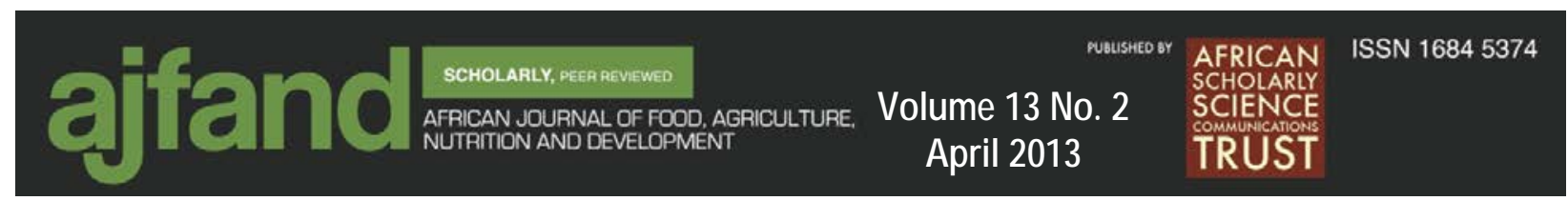

normal times, food scarcity and famine periods, 6) fast regeneration under trace moisture and short life cycle, 7) availability of edible part during collection time, 8) safety of the edible part as confirmed by informants, and 9) high value for Index of Ingestion, a new index used to evaluate stomach fill and proximate nutritional benefit from the edible part which is indicated as follows:

$$
I I=\frac{W I}{W O} \times 100
$$

Where II is index of ingestion, WO is fresh weight of gross plant part that reaches the oral cavity and WI is fresh weight of plant part ingested or swallowed, literally this is WO minus the inedible part discarded from the mouth. The value of II before converting to percentage scale ranges from little more than zero to one, and little more than 0-100 in terms of percentage. Values near zero are indications of insignificant level of ingestible material from the edible part, and values approaching 100 are indications for higher percent of the edible plant part available as per os for ingestion. A method for estimating the proportion of actual ingested part from the gross plant material available to bite or take into the oral cavity was lacking. This index was developed in the course of the present research and used to compare the ingestible portions of wild edible plants. For the sake of comparison, edible portions of Coccinia grandis and Trigonella foenum-graecum which were collected from Mysore, India were also considered for the analysis.

\section{Edible plant part collection and processing}

Edible parts of the 15 selected semi-wild and wild plant species were collected in the morning hours (6.00 AM to 9.00 AM) from Hamar or Konso, the principal researcher being guided by local participants. The collected materials were then washed using running water, transported and stored under freezing condition at the Ethiopian Health and Nutrition Research Institute in Addis Ababa. Samples were freeze-dried, ground to fine powder in a mixer grinder and sieved through an $80 \mathrm{~mm}$ mesh. The pulverized materials were stored in umber bottles and taken to Central Food Technology Research Institute, Mysore, India for chemical analysis. The materials collected from Mysore were also processed similarly.

\section{Chemical analysis}

Proximate composition, selected minerals and anti-nutritional factors of the pulverized materials were determined using standard methods. Moisture, ash, fat and crude protein were estimated using the methods of AOAC [17]. Crude fibre was determined using the neutral detergent fibre estimation method [18] and carbohydrates were obtained by calculating the difference (the sum of protein, fat, ash and crude fibre on dry basis is subtracted from 100). Minerals, viz. calcium, iron, magnesium, manganese, zinc and copper were estimated using AOAC official methods 999.11/985.35 [17]. Anti-nutritional factors, viz. phenolics [19] and tannins [20-22] were estimated spectrophotometrically as gallic acid and catechin equivalents, respectively. Total oxalate was determined using HPLC [23]. Amino acids were analysed by HPLC following the method of Bidlingmeyer and co-workers 


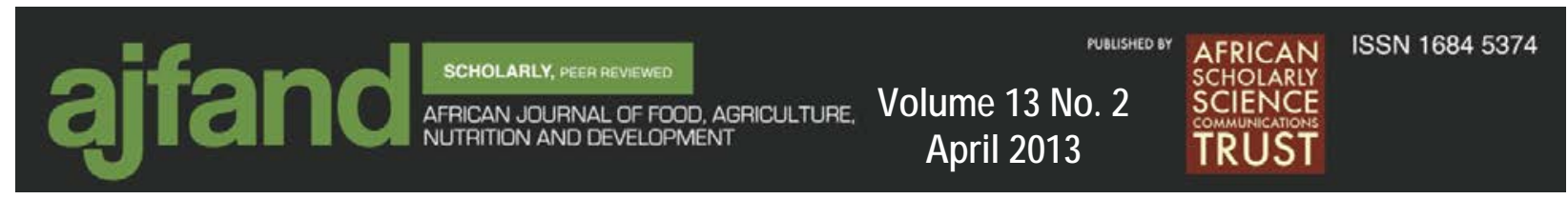

[24]. Tryptophan, methionine and cystine were not estimated due to their decomposition by hydrolysis. Moreover, due to hydrolysis of asparagine and glutamine during digestion, they were estimated in the pooled state as aspartic acid and glutamic acid, respectively.

\section{Statistical analysis of data}

Descriptive statistical analysis was used to calculate means and SD. Correlation analysis was made for determination of oxalic acid (standard) and peak area at the selected HPLC conditions in order to see their positive linear relationships and proceed to estimation of the oxalic acid contents of the edibles.

\section{RESULTS}

\section{Nutritional composition of semi-wild and wild edibles}

The 15 semi-wild and wild edible plants assayed belong to taxonomically wide groups in 11 families and 15 genera (Table 1). They consist of 13 GLVs, one fruit and a tuber-producing species. Nutritional compositions of the edible parts of these plants are presented in Tables 2 and 3. Among the edible plant parts tested, aerial succulent parts of $P$. quadrifida and $P$. laticoronum respectively contained moisture in the order of $90.9 \%$ and $90.5 \%$ on fresh weight (fw) basis. Fruits of Ximenia caffra and leaves of Balanites aegyptiaca have the lowest moisture content with $61.2 \%$ and $63.5 \%$, respectively. Ether extractive (fat and pigments) of $A$. gomboczianus tuber was the least of all tested samples with $0.4 \%$ dry matter basis $(\mathrm{dmb})$ followed by the vegetables ranging from $1.5 \%$ in C. trilocularis to $5.5 \%$ in L. hastata. Ximenia caffra has the maximum level of ether extractive (23.6\% dmb).

Relatively high protein contents were recorded for C. grandis (36.3\%), J. flava (32.9\%), C. argentea (32.7\%) and P. insipidum (32.3\%), while A. gomboczianus, $P$. laticoronum and $P$. quadrifida have the least with 5.8, 8.1 and $19.6 \%$, respectively. Comparatively, the protein contents of $C$. grandis and $T$. foenum-graecum which were collected from India were 28 and $28.7 \%$ dmb, respectively. The amino acids of the latter two species, which were separated within 11.5 minutes in HPLC, were further quantified. The detectable 19 amino acids including glutamine and asparagine as glutamic and aspartic acids, respectively, are presented in Figure 1 and Table 5 in the order of their elution. Both these vegetables (C. grandis and T. foenum-graecum) are rich in essential amino acids. Tryptophan was not detected, methionine and cystine were present in trace amounts and asparagine and glutamine were estimated as aspartic and glutamic acids, respectively. 

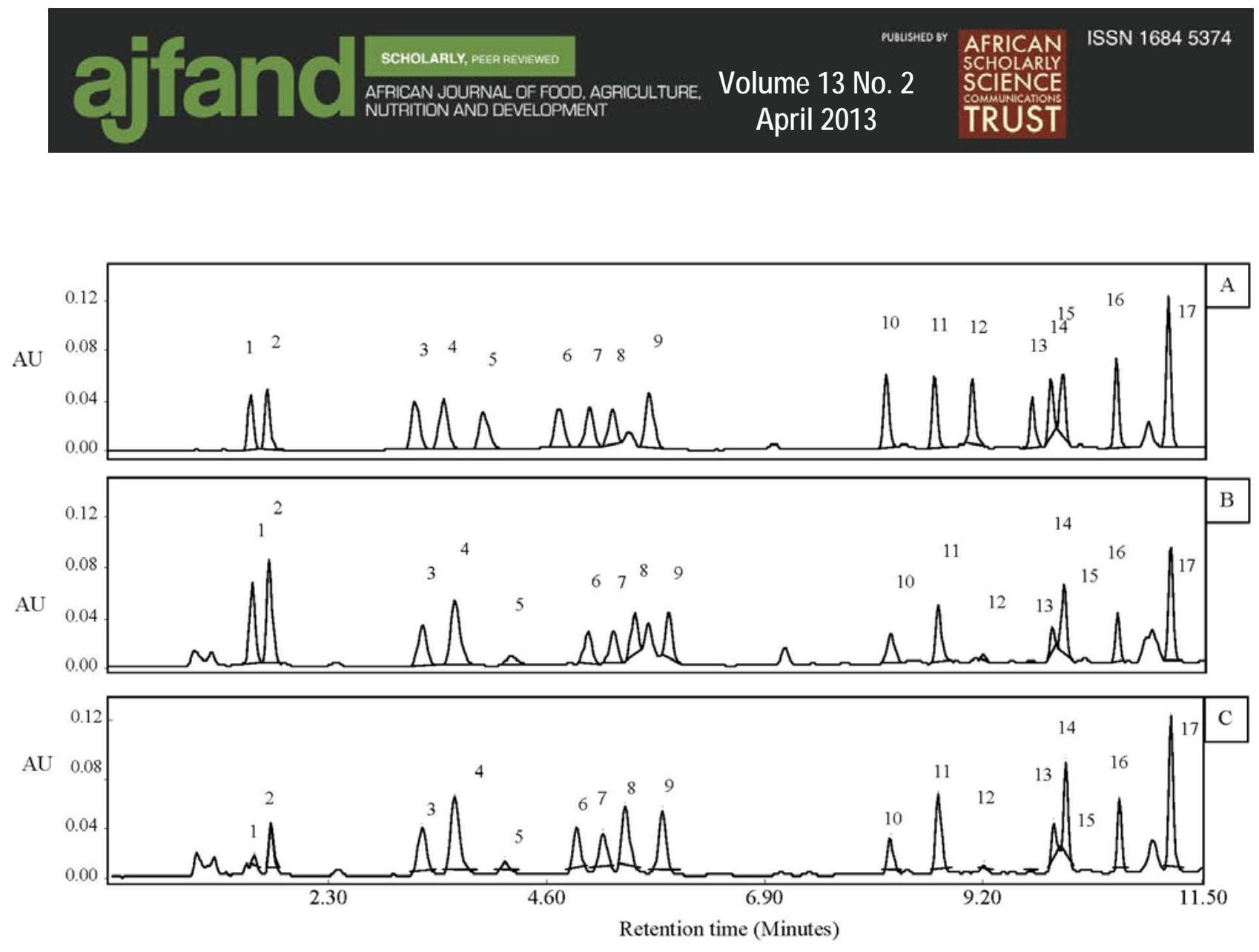

Figure 1: Analysis of standard amino acids and vegetable hydrolysates

$\mathrm{A}=$ Standard amino acids; $\mathrm{B}=T$. foenum-graecum, and $\mathrm{C}=C$. grandis .

Chromatographic conditions are described in the text and numbers on peaks are amino acids as described in Table 5

The highest ash (total minerals) content was recorded for the green vegetables ranging from $12.5 \%$ in $B$. aegyptiaca to $25.6 \%$ in $J$. flava. The fruit (X. caffra) and tuber (A. gomboczianus) were found to be poor sources of minerals with $5 \%$ and $6 \%$ $\mathrm{dmb}$, respectively. Among the minerals assayed in the present study, calcium was predominant in all the vegetables followed by magnesium (Table 3). Exceptionally high level of calcium was recorded for J. ladanoides $(6177 \mathrm{mg} \% \mathrm{dmb}$ ). The other GLVs contained calcium levels ranging from 1100 in P. insipidum to $3419 \mathrm{mg} \%$ in $J$. flava dmb. The level of magnesium in the GLVs ranged between 175 in $C$. trilocularis to $2049 \mathrm{mg} \% \mathrm{dmb}$ in A. graecizans. Launaea intybacea, J. ladanoides, J. flava and P. quadrifida were found to have higher iron content of 22, 21.2, 20.6 and $20.1 \mathrm{mg} \% \mathrm{dmb}$, respectively, and C. grandis was the least with $13 \mathrm{mg} \% \mathrm{dmb}$. The manganese content of the GLVs ranged from $3.4 \mathrm{mg} \%$ in B. aegyptiaca to $9.9 \mathrm{mg} \%$ $\mathrm{dmb}$ in L. intybacea. Justicia ladanoides, L. intybacea, and A. ellenbeckii were also rich in zinc with 3.3, 3.12 and $3.08 \mathrm{mg} \% \mathrm{dmb}$, respectively. However, B. aegyptiaca was very poor source of zinc (1.1 mg \% dmb). Furthermore, J. flava, L. intybacea and C. argentea contained substantial quantities of copper with $1.48,1.45$ and $1.39 \mathrm{mg} \%$, whereas, $P$. insipidum, $P$. laticoronum and $A$. ellenbeckii were in the lower strata with $0.41,0.43$ and $0.54 \mathrm{mg} \% \mathrm{dmb}$, respectively. Both species of Justicia contained good and comparable amounts of the minerals assayed except their variation in calcium and magnesium. The tuber of $A$. gomboczianus contained highest level of carbohydrate 


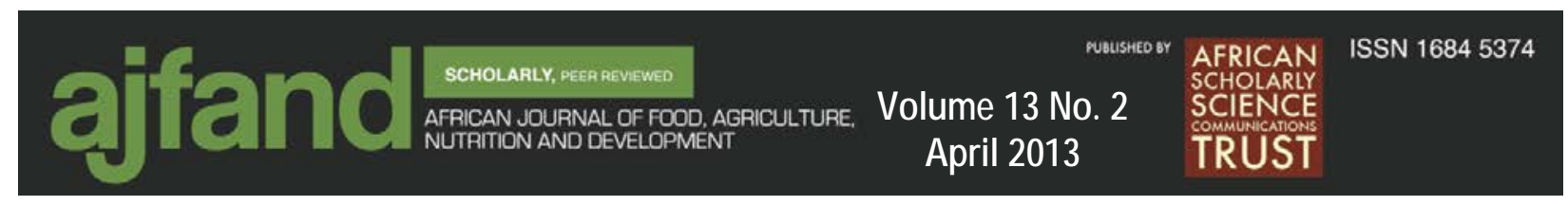

and energy value with $83.5 \%$ and $333.8 \mathrm{Kcal}$, and C. argentea has the least with $30.7 \%$ and $122.9 \mathrm{Kcal}$, respectively (Table 2 ).

\section{Anti-nutritional factors in semi-wild and wild edibles}

The total phenolics, tannins and oxalates for all species are presented in Table 4. The total phenolics content as gallic acid equivalent of the green vegetables was within the range of 158 in L. intybacea to $1564 \mathrm{mg} \% \mathrm{dmb}$ in $P$. insipidum. The level of tannins as catechin equivalent in the GLVs varied from 448 in P. laticoronum to 2254 mg \% in A. ellenbeckii. Of all the samples tested, the tuber of A. gomboczianus had the least level of phenolics (100 $\mathrm{mg} \% \mathrm{dmb}$ ) and tannins (40 $\mathrm{mg} \% \mathrm{dmb}$ ), and $X$. caffra has the highest with 1997 and 6314 mg \% g, respectively. During oxalic acid determination, linear relationship of the standard oxalic acid and peak area was obtained at the selected HPLC conditions $(\mathrm{r}=0.998)$. Known concentrations of oxalic acid as well as extract of $A$. gomboczianus tuber (aroid), which is known for its burning and irritating sensations, were used as internal quality control of the retention time and area of the peaks for total oxalate. The standard and extract were run intermittently as singlet and in combination to monitor the precision of the total and soluble oxalate determination. The study showed minimum level of total oxalate in $P$. laticoronum, C. grandis and L. hastata having 238, 440 and $462 \mathrm{mg} \%$, respectively. On the other hand, A. graecizans, $C$. argentea and $P$. quadrifida contained the highest level of oxalic acid with 14067, 12706 and $10162 \mathrm{mg} \%$ dmb, respectively.

\section{DISCUSSION}

In general, the level of nutritional and anti-nutritional factors of the underutilized edible plants studied was comparable with that found in conventional crops. Ash content of the study edibles was comparable or higher than other wild and domesticated GLVs reported by other researchers [25-27]. Except Justicia ladanoides, which showed high calcium level, the calcium and magnesium contents of all the vegetables were within the range for GLVs reported by different investigators [25-27]. The manganese content of the leafy greens was mostly higher than that reported for underutilized leafy vegetables of India [26,27] and Nigeria [28]. With few exceptions, Justicia ladanoides and J. flava contained comparable (except calcium and magnesium) and higher levels of the minerals assayed. As species in the same genus, this similarity in chemical composition may be attributed to their phylogenetic closeness. The variation in calcium and magnesium could be attributed to one or more factors of genetic, environmental or growth stage of the vegetable during collection. Among the GLVs, B. aegyptiaca and $P$. insipidum leaves appear to contain low levels of the minerals. As expected, fruits of $X$. caffra and tuber of $A$. gomboczianus contained the least level of all the minerals assayed.

With the exception of $P$. laticoronum, the level of protein (dmb) in all the test vegetables is comparable with that of pulses $[10,11]$. Similarly, C. grandis and $T$. foenum-graecum which were collected from Mysore, India, and analysed for their amino acid levels have proved to be rich sources of lysine, which is the main limiting amino acid in cereal grains. Gradual reduction in the level of lysine during storage 


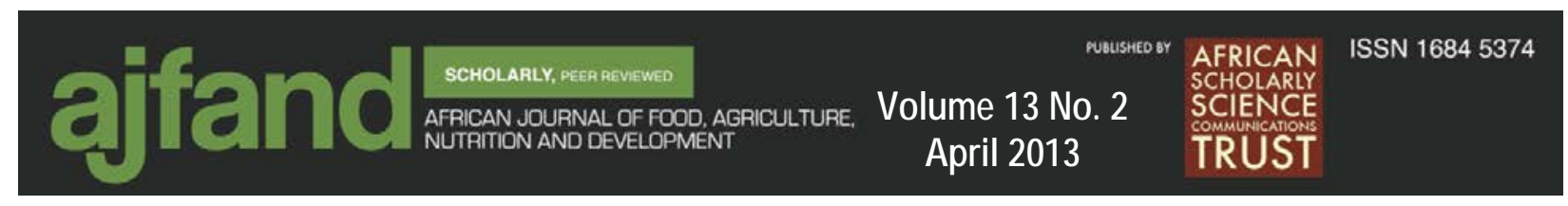

has been reported [29]. Analysis of amino acids was, therefore, made on freshly dried edible portions of the GLVs procured from Mysore. The dried plant materials from Ethiopia had been stored for 37 days prior to chemical analysis and hence not suitable for amino acid analysis since lysine is believed to undergo degradation. However, it can be inferred that the GLVs from south Ethiopia may give high level of lysine as supported by the present study on the two GLVs and other findings [27]. Although methionine and cystine were not estimated due to acid hydrolysis [24], vegetables are generally known to be deficient in sulphur-containing amino acids [27]. Cereals being the staple foods of the Hamar and Konso communities, it can safely be assumed that consumption of the same vegetables with cereal diets may help to achieve adequate amounts of sulphur-containing amino acids in diets. However, the amount of lysine that can be obtained from grains may not meet the daily recommended level of the same [30]. It is also unlikely that majority of the population in developing countries use the required quantity of animal products to complement daily lysine requirement. Use of leafy vegetables, possibly completely dried at 40 to $45^{\circ} \mathrm{C}$ under dark condition or shade [12] can, therefore, contribute in prevention and amelioration of protein malnutrition in the study communities and developing countries at large. Further study on this aspect is expected to shed more light and elucidate in vivo bioavailablity of the protein present in each GLV.

The levels of phenolics including tannins in the presently studied GLVs fall within the range of previously reported values of domesticated and wild GLV [26]. Based on the available information on the effect of tannins in reducing digestibility of proteins [13], consumption of vegetables and fruits with such high tannin content may not be encouraged. However, the plant materials, which contained higher level of phenolic compounds, can potentially be good antioxidants [31]. Further in vitro and in vivo antioxidant activity studies may generate very useful information about these and other wild edibles.

Oxalic acid is generally known to be widely distributed across different GLVs [26]. The oxalic acid content of the study GLVs appears to be higher than what has been previously reported by various authors on the same or other vegetables [26,27,32]. Variation in the level of oxalic acid could be attributed to difference in genetic, environmental, plant part collected and its growth stage as well as the method of analyses. As suggested by Judprasong and co-workers [32], the HPLC method employed in the present experiment is relatively sensitive and accurate than the colourimetric, titrimetric and other methods. Moreover, A. graecizans and $C$. argentea (Amaranthaceae), P. quadrifida (Portulacaceae) and B. aegyptiaca (Balanitaceae) contained higher levels of oxalic acid. High level of oxalic acid was previously reported in species that belong to Amaranthaceae [33] and Portulacaceae [34]. The same sources also contained similar information on the effect of oxalate compounds in chelating bivalent minerals such as calcium and iron. This has serious negative implications to health, particularly vulnerable groups viz. children, pregnant and lactating mothers that require more calcium and iron. Given that vegetables contain higher level of moisture, sporadic consumption of nominal quantity may not be detrimental to health. However, it would be appropriate to avoid bulk consumption 


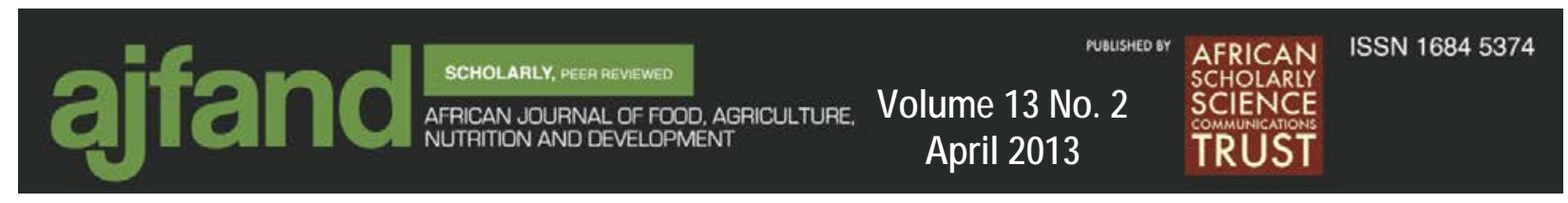

of the vegetables which contain high level of tannins including phenolics and oxalate compounds in one meal or use as main diet.

\section{CONCLUSION AND RECOMMENDATIONS}

This study showed that the GLVs studied are good sources of nutrients including minerals such as $\mathrm{Ca}, \mathrm{Mg}, \mathrm{Fe}, \mathrm{Zn}$ and $\mathrm{Mn}$, which are comparable with or sometimes higher than conventional GLVs. They also have good fibre content and quality protein which is rich in lysine, an amino acid limiting in cereals. The results offer important ground to rank the wild edibles on the basis of organoleptic properties provided by local participants and the chemical data, and prepare food composition tables, an important feature of which will be the integration of indigenous knowledge with chemical information. Therefore, most of these underutilized edibles can be used to mitigate micro- and macronutrient malnutrition and improving food security. This can be done following serious consideration on the level of anti-nutritional composition in each of the edible plant parts and existing processing technologies that can be used for eradication or significant reduction of the respective anti-nutrients. The level of each anti-nutritional factor, viz. total phenolics, tannins and total oxalic acid, varied among the different edible plant parts. Higher moisture content and traditional home-based processing methods reduce the level of anti-nutritional factors in GLVs making them suited for rational utilization. Therefore, consumption of most of the GLVs can safely be assumed harmless if taken as side dish or part of the meal. If the GLVs are dried for use, taking higher amount of the same per serving or at higher frequency may deter bioavailability of nutrients which may further lead to macro- and micronutrient deficiency or cause health problems. Higher intake of oxalate is known to cause renal disorder by forming kidney stones in humans. Therefore, excess intake of GLVs that are rich in oxalate should be limited to promote better absorption of minerals and prevent internal health problems. GLVs of wild and semi-wild origin contain nutrients and anti-nutritional factors comparable to cultivated green vegetables.

Indigenous wild and semi-wild GLVs are adapted to the marginal agroclimatic conditions of their common occurrence. Moreover, unlike the domesticated GLVs that may require higher input for production, wild vegetables can easily be harvested from gardens, farmlands or other habitats. Promotion of vegetables tends to be less expensive all the way from production to processing and can be accessible at times of food shortage. Therefore, some of them can be selected and developed as future crops under the scenario of fast climate change and deterioration of natural resources. Effective and aggressive multifaceted programmes of conservation, promotion and sustained utilization of wild edibles are in the best interest of rural development in Ethiopia and other developing countries. In the short term, selection and domestication of healthy, nutritious and agronomically geared up underutilized GLVs is suggested. This should be supported by an all round strategy that includes promotion and educational intervention at local community level. 


\section{Acknowledgements}

This work was financially supported by the United Nations University through the Institute of Natural Resources for Africa. The Central Food and Technological Research Institute (India) provided the research facilities. The principal author acknowledges Biology Department of Addis Ababa University and Ethiopian Health and Nutrition Research Institute (Ethiopia) for their kind permission to work on this project. We thank Dr. N.G. Malleshi and Dr. V. Prakash for guidance on the analytical aspects. 
Table 1: Edible semi-wild and wild plants from south Ethiopia screened for nutritional and non-nutritional compositions

\begin{tabular}{|c|c|c|}
\hline Scientific name & Local name $^{c}$ & Family \\
\hline Adenia ellenbekii Harms & Armulo $^{1}$, Qaqula ${ }^{2}$ & Passifloraceae \\
\hline Amaranthus graecizans L. & Zapina $^{1}$, Rasuta ${ }^{2}$ & Amaranthaceae \\
\hline Amorphophallus gomboczianus Pichi-Serm. ${ }^{a}$ & Paganna/Pakanna/Poganna ${ }^{2}$ & Araceae \\
\hline Balanites aegyptiaca (L.) Del. & Domoko $^{1}$, Hankalta/Hangalta ${ }^{2}$ & Balanitaceae \\
\hline Celosia argentea $\mathrm{L}$. & Torchata/Torcha/Horbaita ${ }^{2}$ & Amaranthaceae \\
\hline Coccinia grandis (L.) Voigt & Gulo/Kulo/Gungulo ${ }^{1}$, Lacheta ${ }^{2}$ & Cucurbitaceae \\
\hline Corchorus trilocularis (L.) & $\begin{array}{l}\text { Lagi/Loqe/Kilanqigusho }{ }^{1} \text {, } \\
\text { Oloqloqota/Hachota }^{2}\end{array}$ & Tiliaceae \\
\hline Justicia flava (Vahl) Vahl & Honnona $^{2}$ & Acanthaceae \\
\hline Justicia ladanoides Lam. & Qira/Qirqira² & Acanthaceae \\
\hline Launaea intybacea (Jacq.) Beauverd & Morde $^{1}$, Hankolayta ${ }^{2}$ & Asteraceae \\
\hline Leptadenia hastata (Pers.) Decne. & Meta $^{1}$, Xeyla ${ }^{2}$ & Asclepiadaceae \\
\hline $\begin{array}{l}\text { Pachycymbium laticoronum (M.G. Gilbert) M.G. } \\
\text { Gilbert }\end{array}$ & Baqbaqa/Pappaqa/Parapaqa² & Asclepiadaceae \\
\hline Pentarrhinum insipidum E. Mey. & $\begin{array}{l}\text { Shabena/Shavena }{ }^{1} \text {, } \\
\text { Kokordota/Kordota }^{2}\end{array}$ & Asclepiadaceae \\
\hline Portulaca quadrifida L. & $\begin{array}{l}\text { Muleza/Mulaza } \\
\text { Maraeitta//Mecheritta }^{2}\end{array}$ & Portulacaceae \\
\hline Ximenia caffra Sond ${ }^{\mathrm{b}}$ & Moqela $^{1}$, Hinkiketa ${ }^{2}$ & Olacaceae \\
\hline
\end{tabular}

${ }^{\mathrm{a}}$ Tuber; ${ }^{\mathrm{b}}$ Fruit; ${ }^{\mathrm{c}}$ local name in ${ }^{1}$ Hamar and ${ }^{2}$ Afa-Konso languages in Southern Ethiopia 


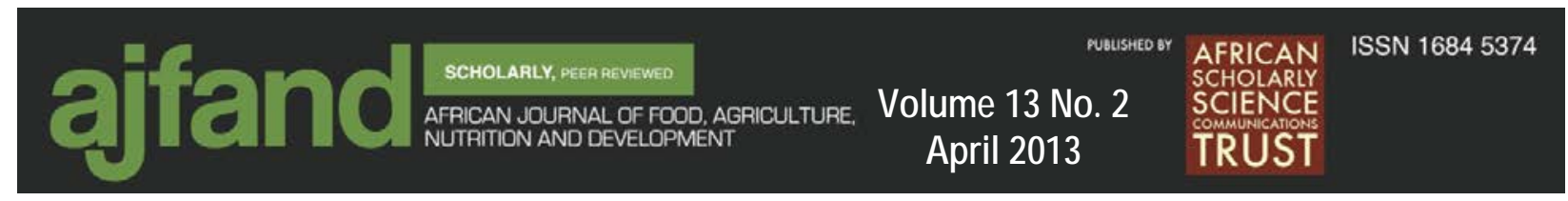

Table 2: Proximate composition (g/ 100 g) of some semi-wild and wild green leafy vegetables and other local wild foods

\begin{tabular}{|c|c|c|c|c|c|c|c|}
\hline & & & Ether & & Crude & Carbo- & \\
\hline Scientific name ${ }^{a}$ & $\begin{array}{l}\text { Moisture } \\
\text { (fw) }\end{array}$ & $\begin{array}{c}\text { Ash } \\
\text { (dmb) }\end{array}$ & $\begin{array}{c}\text { extractives } \\
\text { (dmb ) }\end{array}$ & $\begin{array}{l}\text { Protein } \\
\text { (dmb) }\end{array}$ & $\begin{array}{l}\text { fiber } \\
\text { (dmb) }\end{array}$ & $\begin{array}{c}\text { hydrate } \\
\text { (dmb) }\end{array}$ & $\begin{array}{c}\text { Energy } \\
\text { (Kcal, dmb) }\end{array}$ \\
\hline Adenia ellenbeckii & $83.6 \pm 0.3$ & $13.8 \pm 0.1$ & $5.0 \pm 0.1$ & $27.7 \pm 0.2$ & $10.0 \pm 0.6$ & 43.5 & 174.1 \\
\hline Amaranthus graecizans & $72.7 \pm 0.3$ & $22.0 \pm 0.1$ & $3.9 \pm 0.4$ & $28.5 \pm 0.2$ & $8.5 \pm 0.8$ & 37.1 & 148.2 \\
\hline Balanites aegyptiaca & $63.5 \pm 1.2$ & $12.5 \pm 0.1$ & $2.5 \pm 0.8$ & $28.8 \pm 0.4$ & $15.5 \pm 0.3$ & 40.7 & 162.6 \\
\hline Celosia argentea & $84.1 \pm 0.3$ & $23.9 \pm 0.5$ & $2.9 \pm 0.8$ & $32.7 \pm 0.1$ & $9.8 \pm 0.1$ & 30.7 & 122.9 \\
\hline Coccinia grandis & $78.5 \pm 0.7$ & $15.2 \pm 0.1$ & $3.5 \pm 0.1$ & $36.3 \pm 0.2$ & $10.1 \pm 0.6$ & 34.9 & 139.6 \\
\hline Corchorus trilocularis & $83.9 \pm 0.0$ & $15.4 \pm 0.8$ & $1.5 \pm 0.3$ & $20.4 \pm 0.2$ & $11.1 \pm 0.9$ & 51.7 & 206.8 \\
\hline Justicia flava & $80.6 \pm 1.8$ & $25.6 \pm 0.0$ & $2.7 \pm 0.4$ & $32.9 \pm 0.5$ & $7.5 \pm 0.7$ & 31.3 & 125.4 \\
\hline Justicia ladanoides & $73.4 \pm 0.5$ & $25.3 \pm 0.3$ & $2.9 \pm 0.3$ & $25.4 \pm 0.4$ & $12.5 \pm 0.5$ & 33.9 & 135.5 \\
\hline Launaea intybacea & $80.1 \pm 1.3$ & $21.4 \pm 0.3$ & $3.7 \pm 0.1$ & $24.1 \pm 0.2$ & $10.7 \pm 0.1$ & 40.1 & 160.3 \\
\hline Leptadenia hastata & $76.9 \pm 1.6$ & $13.8 \pm 0.2$ & $5.5 \pm 0.1$ & $20.3 \pm 0.8$ & $14.9 \pm 0.2$ & 45.5 & 182.0 \\
\hline Pachycymbium laticoronum & $90.5 \pm 0.8$ & $13.2 \pm 0.2$ & $3.1 \pm 0.5$ & $8.1 \pm 0.4$ & $15.1 \pm 0.2$ & 60.5 & 242.1 \\
\hline Pentarrhinum insipidum & $77.0 \pm 0.8$ & $15.5 \pm 0.6$ & $3.3 \pm 0.1$ & $32.3 \pm 0.2$ & $10.9 \pm 0.2$ & 38.0 & 151.9 \\
\hline Portulaca quadrifida & $90.9 \pm 0.5$ & $24.6 \pm 0.8$ & $3.1 \pm 0.2$ & $19.6 \pm 0.1$ & $15.9 \pm 0.2$ & 36.8 & 147.3 \\
\hline \multicolumn{8}{|l|}{ Amorphophallus } \\
\hline gomboczianus $^{\text {b }}$ & $84.5 \pm 0.4$ & $6.0 \pm 0.2$ & $0.4 \pm 0.1$ & $5.8 \pm 0.1$ & $4.3 \pm 0.0$ & 83.5 & 333.8 \\
\hline Ximenia caffra $^{\mathrm{c}}$ & $61.2 \pm 0.6$ & $5.0 \pm 0.2$ & $23.6 \pm 1.0$ & $21.6 \pm 0.1$ & $10.4 \pm 1.4$ & 39.4 & 157.5 \\
\hline Coccinia grandis $^{\mathrm{d}}$ & $87.3 \pm 0.5$ & $15.9 \pm 0.2$ & $5.2 \pm 0.2$ & $28.7 \pm 0.4$ & ND & ND & ND \\
\hline Trigonella foenum-graecum ${ }^{\mathrm{d}}$ & $89.8 \pm 1.1$ & $23.8 \pm 0.4$ & $5.8 \pm 0.3$ & $28.0 \pm 0.7$ & ND & ND & ND \\
\hline
\end{tabular}

${ }^{\mathrm{a}}$ All are green vegetables, unless otherwise mentioned; ${ }^{\mathrm{b}}$ Tuber; ${ }^{\mathrm{c}}$ Fruit; ${ }^{\mathrm{d}} \mathrm{GLV}$ from India; ND = Not Determined; Values are means of three independent analyses of composite samples \pm SD 
Table 3: Mineral (mg \% dmb) composition of some semi-wild and wild green vegetables and other wild foods

\begin{tabular}{|c|c|c|c|c|c|c|}
\hline Scientific name $^{a}$ & Ca & $\mathbf{C u}$ & Fe & Mg & Mn & Zn \\
\hline Adenia ellenbeckii & 1239 & 0.54 & 16.6 & 404 & 7.8 & 3.1 \\
\hline Amaranthus graecizans & 3029 & 0.65 & 19.3 & 2049 & 7.2 & 2.3 \\
\hline Balanites aegyptiaca & 2487 & 0.61 & 13.5 & 701 & 3.4 & 1.2 \\
\hline Celosia argentea & 2207 & 1.39 & 19.8 & 824 & 9.1 & 2.2 \\
\hline Coccinia grandis & 3064 & 0.60 & 13.0 & 433 & 5.6 & 2.5 \\
\hline Corchorus trilocularis & 1767 & 0.68 & 18.6 & 175 & 8.4 & 2.9 \\
\hline Justicia flava & 3419 & 1.48 & 20.6 & 547 & 8.4 & 2.7 \\
\hline J. ladanoides & 6177 & 1.17 & 21.2 & 1026 & 7.4 & 3.3 \\
\hline Launaea intybacea & 2070 & 1.45 & 22.0 & 437 & 9.9 & 3.1 \\
\hline Leptadenia hastata & 1699 & 0.59 & 14.2 & 214 & 4.2 & 2.0 \\
\hline Pachycymbium laticoronum & 1128 & 0.43 & 13.2 & 309 & 9.8 & 2.4 \\
\hline Pentarrhinum insipidum & 1100 & 0.41 & 16.3 & 183 & 6.2 & 2.1 \\
\hline Portulaca quadrifida & 2193 & 0.87 & 20.1 & 1094 & 6.8 & 2.9 \\
\hline Amorphophallus gomboczianus ${ }^{\mathrm{b}}$ & 428 & 0.08 & 8.72 & 109 & 1.9 & 1.1 \\
\hline Ximenia caffra ${ }^{\mathrm{C}}$ & 180 & 0.58 & 1.9 & 110 & 1.1 & 1.3 \\
\hline Trigonella foenum-graecum ${ }^{\mathrm{d}}$ & 1038 & 3.2 & 23.14 & 203.5 & ND & 1.0 \\
\hline Coccinia grandis $^{\mathrm{d}}$ & ND & 3.5 & 11.7 & 756.0 & ND & 1.2 \\
\hline
\end{tabular}

${ }^{\mathrm{a}}$ All are green vegetables, unless otherwise mentioned; ${ }^{\mathrm{b}}$ Tuber; ${ }^{\mathrm{c}}$ Fruit; ${ }^{\mathrm{d}}$ Sample collected from India; ND = Not Determined; Values are expressed as mean of two independent analyses on dmb 
Table 4: Some important non-nutritional compositions (mg \% dmb) of selected semi-wild and wild Ethiopian green vegetables and other wild foods

\begin{tabular}{|c|c|c|c|}
\hline Scientific name $^{a}$ & $\begin{array}{c}\text { Phenols } \\
\text { (gallic acid equivalent) }\end{array}$ & $\begin{array}{c}\text { Tannins } \\
\text { (catechin equivalent) }\end{array}$ & Total oxalate \\
\hline Adenia ellenbeckii & $1219 \pm 9$ & $2254 \pm 34$ & $2603 \pm 33$ \\
\hline Amaranthus graecizans & $328 \pm 5$ & $1537 \pm 78$ & $14067 \pm 60$ \\
\hline Amorphophallus gomboczianus ${ }^{\mathrm{b}}$ & $100 \pm 3$ & $40 \pm 14$ & $1064 \pm 5$ \\
\hline Balanites aegyptiaca & $995 \pm 6$ & $718 \pm 50$ & $4630 \pm 132$ \\
\hline Celosia argentea & $323 \pm 4$ & $1410 \pm 26$ & $12706 \pm 16$ \\
\hline Coccinia grandis & $311 \pm 8$ & $1562 \pm 53$ & $440 \pm 43$ \\
\hline Corchorus trilocularis & $281 \pm 3$ & $951 \pm 28$ & $3443 \pm 198$ \\
\hline Justicia flava & $289 \pm 19$ & $995 \pm 19$ & $3613 \pm 12$ \\
\hline Justicia ladanoides & $189 \pm 1$ & $1349 \pm 11$ & $2212 \pm 115$ \\
\hline Launaea intybacea & $158 \pm 1$ & $1103 \pm 11$ & $832 \pm 6$ \\
\hline Leptadenia hastata & $649 \pm 13$ & $865 \pm 92$ & $462 \pm 8$ \\
\hline Pachycymbium laticoronum & $359 \pm 8$ & $448 \pm 11$ & $238 \pm 6$ \\
\hline Pentarrhinum insipidum & $1564 \pm 33$ & $1587 \pm 26$ & $1612 \pm 30$ \\
\hline Portulaca quadrifida & $908 \pm 17$ & $853 \pm 44$ & $10162 \pm 180$ \\
\hline Ximenia caffra ${ }^{\mathrm{c}}$ & $1997 \pm 31$ & $6314 \pm 451$ & $2134 \pm 4$ \\
\hline Trigonella foenum-graecum ${ }^{\mathrm{d}}$ & 729 & 1275 & 357 \\
\hline Coccinia grandis ${ }^{\mathrm{d}}$ & 749 & 1958 & 504 \\
\hline
\end{tabular}

${ }^{\mathrm{a}}$ All are green vegetables, unless otherwise mentioned; ${ }^{\mathrm{b}}$ Tuber; ${ }^{\mathrm{c}}$ Fruit; ${ }^{\mathrm{d}}$ Sample collected from India; Values are means of three independent analyses of composite samples on dmb $\pm \mathrm{SD}$ 
Table 5: Amino acid composition (g/ $100 \mathrm{~g}$ protein) of freshly collected samples (Coccinia grandis and Trigonella foenum-graecum) from India

\begin{tabular}{|c|c|c|c|}
\hline \multirow{2}{*}{$\begin{array}{c}\text { Peak number on } \\
\text { HPLC } \\
\text { chromatogram*** }\end{array}$} & \multirow[t]{2}{*}{ Amino acid } & \multicolumn{2}{|c|}{ Vegetables } \\
\hline & & $\begin{array}{l}\text { Coccinia } \\
\text { grandis }\end{array}$ & $\begin{array}{c}\text { Trigonella } \\
\text { foenum-graecum }\end{array}$ \\
\hline 1 & $\mathrm{Asx}^{*}$ & $1.82 \pm 0.12$ & $11.53 \pm 0.31$ \\
\hline 2 & Glx** & $6.37 \pm 0.50$ & $14.16 \pm 0.32$ \\
\hline 3 & Serine & $6.54 \pm 0.25$ & $5.74 \pm 0.10$ \\
\hline 4 & Glycine & $7.08 \pm 0.09$ & $6.51 \pm 0.13$ \\
\hline 5 & Histidine & $2.56 \pm 0.20$ & $2.25 \pm 0.24$ \\
\hline 6 & Arginine & $9.93 \pm 0.02$ & $7.28 \pm 0.32$ \\
\hline 7 & Threonine & $6.24 \pm 0.06$ & $5.41 \pm 0.10$ \\
\hline 8 & Alanine & $10.00 \pm 0.10$ & $5.82 \pm 0.57$ \\
\hline 9 & Proline & $6.89 \pm 0.26$ & $5.35 \pm 0.09$ \\
\hline 10 & Tyrosine & $4.82 \pm 0.14$ & $5.28 \pm 0.11$ \\
\hline 11 & Valine & $7.16 \pm 0.11$ & $5.48 \pm 0.24$ \\
\hline 12 & Methionine & $0.59 \pm 0.16$ & $0.56 \pm 0.04$ \\
\hline 13 & Cysteine & $0.34 \pm 0.11$ & $0.55 \pm 0.03$ \\
\hline 14 & Isoleucine & $4.24 \pm 0.22$ & $3.45 \pm 0.35$ \\
\hline 15 & Leucine & $10.75 \pm 0.14$ & $8.81 \pm 0.41$ \\
\hline 16 & Phenylalanine & $6.93 \pm 0.16$ & $5.24 \pm 0.09$ \\
\hline \multirow[t]{2}{*}{17} & Lysine & $7.74 \pm 0.12$ & $6.59 \pm 0.14$ \\
\hline & Tryptophan & ND & ND \\
\hline
\end{tabular}

$\mathrm{ND}=$ Not detected due to degradation during hydrolysis; * Asx represents both Aspartic acid and Asparagine; ** Glx represents both Glutamine and Glutamic acid; *** HPLC chromatogram is in Figure 1. Values are means of three independent analyses \pm SD 


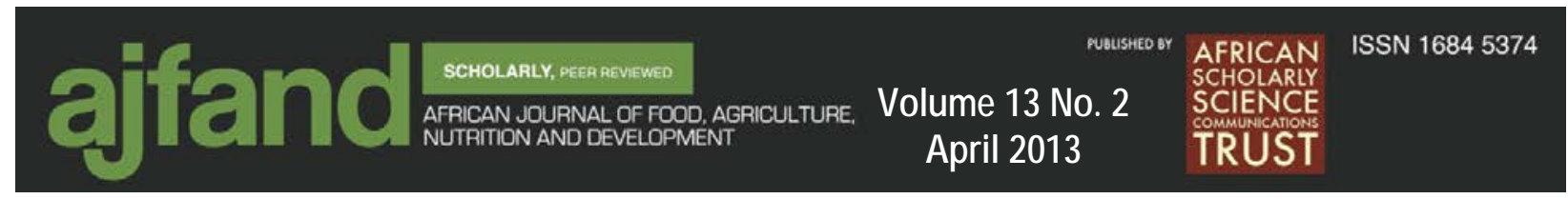

\section{REFERENCES}

1. Teketay D, Senbeta F, Maclachlan $\mathbf{M}$, Bekele $\mathbf{M}$ and $\mathbf{P}$ Barklund Edible Wild Plants in Ethiopia. Addis Ababa University Press, Addis Ababa, Ethiopia; 2010.

2. Addis G Wild and semi-wild edible plants of Hamar and Xonso (South Ethiopia) with emphasis on their ethnobotany and nutritional composition of selected species. $\mathrm{PhD}$ thesis, Addis Ababa University, Addis Ababa, Ethiopia; 2009.

3. Getahun A The role of wild plants in the native diet in Ethiopia. Agro Ecosystems. 1974; 1: 45 - 56.

4. Asfaw $\mathbf{Z}$ and $\mathbf{M}$ Tadesse Prospects for sustainable use and development of wild food plants in Ethiopia. Econ Bot. 2001; 55(1): 47 - 62.

5. Guinand $\mathbf{Y}$ and D Lemessa A practical field guide to wild-food plants in Ethiopia: general description, edible parts, preparation methods and palatability. UNDPEmergency Unit for Ethiopia, Addis Ababa, Ethiopia; 2001.

6. Addis G, Urga K and D Dikasso Ethnobotanical study of edible wild plants in some selected districts of Ethiopia. Human Ecology. 2005; 33(1): 83 - 118.

7. Wondimu T, Asfaw $\mathbf{Z}$ and $\mathbf{E}$ Kelbessa Ethnobotanical Study of food plants around “Dheeraa” Town, Arsi, Ethiopia. SINET: Ethiop J Sci. 2006; 29(1): 71 - 80.

8. Addis G, Asfaw $\mathbf{Z}$ and $\mathbf{Z}$ Woldu Underutilized edible plants as a means of food source diversification in Ethiopia. In: A. Girma and D. Abate (Eds.), Issues and challenges in food security: Proceedings of a national workshop organized by the Biological Society of Ethiopia. Addis Ababa University, Addis Ababa, Ethiopia; 2009a.

9. Ogle BM and LE Grivetti Legacy of the chameleon: edible wild plants in the Kingdom of Swaziland, Southern Africa. A cultural, ecological, nutritional study. Part II - Demographic, species, availability and dietary use, analysis by ecological zone. Ecol Food Nutr. 1985; 17: 1 - 30.

10. Lakshmi B and V Vimala Nutritive value of dehydrated green leafy vegetable powders. J Food Sci Technol. 2000; 37: 465 - 471.

11. Gupta K, Barat GK, Wagle DS and HK Chawala Nutrient contents and antinutrients factors in conventional and non conventional leafy vegetables. Food Chem. 1989; 31: 105 - 116.

12. Addis G, Baskaran R, Raju M, Ushadevi A, Asfaw Z, Woldu Z and V Baskaran Effect of blanching and drying process on carotenoids composition of underutilized Ethiopian (Coccinia grandis L. Voigt) and Indian (Trigonella foenum-graecum L.) green leafy vegetables. J Food Process Pres. 2009b; 33: 744 - 762. 


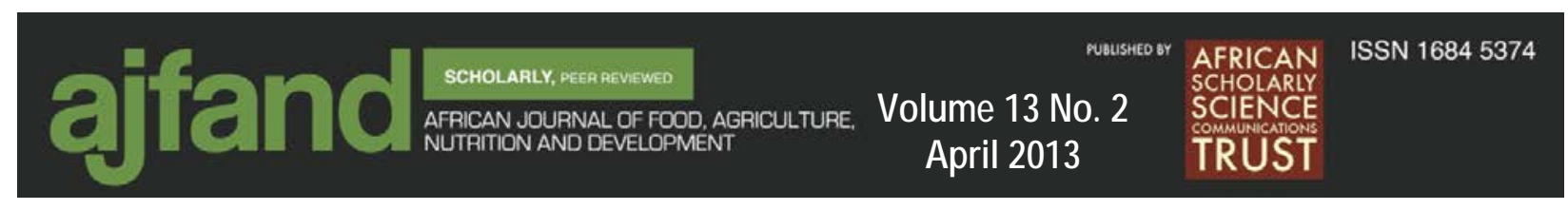

13. Thompson LU Potential health benefits and problems associated with antinutrients in foods. Food Res Int. 1993; 26: 131 - 149.

14. Johns T, Mahunnah RLA, Sanaya P, Chapman $\mathbf{L}$ and T Ticktin Saponins and phenolic content in plant dietary additives of a traditional subsistence community, the Batemi of Ngorongoro District, Tanzania. J Ethnopharmacol. 1999; 66 (1): 1 - 10.

15. International Work Group for Indigenous Affairs Declaration on the rights of indigenous peoples. URL: http://www.iwgia.org/sw248.asp. 2007; Accessed May 8, 2009.

16. Martin GJ Ethnobotany: A ‘People and Plants' Conservation Manual. Chapman and Hall, London. 1995.

17. AOAC. Official methods of the AOAC International. Determination of lead, cadmium, and minerals in foods by Atomic Absorption spectrophotometry (method 999.11/985.35). Association of Official Analytical Chemists, Gaithersburg. 2000.

18. AOAC. Official Methods of Analysis. Herlich, K. (ed), $15^{\text {th }}$ edn. Association of Official Analytical Chemists Intn, Arlington and VA. 1995.

19. Singleton VL and JA Rossi Colorimetry of total phenolics with phosphomolybdiephosphotungstic acid reagents. Am J Enol Viticult. 1965; 48: 2663 - 2669.

20. Burns RR. Methods for estimation of tannins in grain sorghum. Agron J. 1971; 63: $511-512$.

21. Maxon ED and LW Rooney Two methods of tannin analysis for Sorgham bicolor (L.). Moench, grain. Crop Sci. 1972; 12: 253 - 254.

22. Price ML, Scoyoc SV and LGA Buttler Critical evaluation of the vanillin reaction as an assay for tannin in sorghum grain. J Agric Food Chem. 1978; 26: 1214 - 1218.

23. Savage GP, Vanhanen L, Mason SM and AB Ross Effect of cooking on the soluble and insoluble oxalic acid content of some New Zealand foods. J Food Compos Anal. 2000; 13: 201 - 206.

24. Bidlingmeyer BA, Cohen SA, Tarvin TL and B Frost A new, rapid, highsensitivity analysis of amino acids in food type samples. J Assoc Anal Chem. 1987; 70(2): 241 - 247.

25. Wallace PA, Marfo EK and WA Plahar Nutritional quality and anti-nutritional composition of four non-conventional leafy vegetables. Food Chem. 1998; 61(3): 287 - 291.

26. Gupta S, Lakshmi AJ, Manjunath $\mathbf{M}$ and $\mathbf{J}$ Prakash Analysis of nutrient and antinutrient content of underutilized green leafy vegetables. LWT-Food Science and Technology. 2005; 38: 339 - 345. 
27. Gopalan C, Sastri BVR and SC Balasubramanian Revised and updated by Rao BSN, Deosthale YG and KC Pant Nutritive value of Indian foods. National Institute of Nutrition, Indian Council of Medical Research, Hydrabad. 1989.

28. Barminas JT, Charles $\mathbf{M}$ and $\mathbf{D}$ Emmanue Mineral composition of nonconventional leafy vegetables. Plant Foods Hum Nutr. 1998; 53: 29 - 36.

29. Ekberg A, Fields ML and J Edmondson Effect of storage on lysine-enriched corn, millet and sorghum. J Food Sci. 2006; 44(2): 630 - 631.

30. FAO/WHO/UNU Energy and protein requirements; report of a joint FAO/WHO/UNU expert consultation. WHO Tech. Rep. Ser. 724. WHO, Geneva. 1985.

31. Vinson JA and BA Hontz Phenol antioxidant index: comparative antioxidant effectiveness of red and white wines. J Agric Food Chem. 1995; 43: 401 - 403.

32. Judprasong $\mathbf{K}$, Charoenkiatkul S, Sungpuang $\mathbf{P}$, Vasanachitt $\mathbf{K}$ and $\mathbf{Y}$ Nakjamanong Total and soluble oxalate contents in Thai vegetables, cereal grains and legume seeds and their changes after cooking. J Food Comp Anal. 2006; 19(4): 340 - 347.

33. Guil UR, Rodrígez-García I and E Torija Nutritional and toxic factors in selected wild edible plants. Plant Foods Hum Nutr. 1997; 51: 99 - 107.

34. Mathams RH and AK Sutherland. The oxalate content of some Queensland pasture plants. Queensland J Agric Sci. 1952; 9: 317 - 334. 